\title{
TEORI CONTIGUOUS CONDITIONING EDWIN RAY GUTHRIE DAN PENERAPANNYA DALAM PEMBELAJARAN PAI DI SEKOLAH
}

\author{
Ghulamul Mustofa \\ ghulamul.mustofa30@gmail.com \\ UIN Sunan Kalijaga Yogyakarta
}

\begin{abstract}
This article aims to describe the contiguous conditioning theory and its application in Islamic religious education in schools. Contiguous conditioning theory has the meaning of the closeness of conditions that occur based on the relationship between the stimulus and the relevant response. The method used in this research is literature study where the author tries to find, compile and analyze various information through various related sources. The results of this study explain that learning is a process of change that occurs due to conditions which then cause a reaction (response). Some aspects that cannot be separated from this theory are forgetting, punishment, encouragement, intention, and transfer training. Edwin Ray Guthrie came up with three methods that can be used to change habitual behavior, namely the Threshold Method, the Fatigue Method, and the Incompatible Response Method. These three methods can be used by Islamic Education teachers in implementing their learning in the classroom. The positive contribution of this article informs that the contiguous conditioning theory is very suitable to be applied to develop students' abilities both from the cognitive, affective, and psychomotor domains. One way for this theory to work optimally is that the teacher must use interesting learning methods or strategies.
\end{abstract}

\section{Keywords: Contiguous, PAI, Edwin Ray Guthrie}

\begin{abstract}
Abstrak
Artikel ini bertujuan untuk mendeskripsikan teori contiguous conditioning dan penerapanya dalam pembelajaran pendidikan agama islam di sekolah. Teori contiguous conditioning mempunyai makna sebuah kedekatan kondisi yang terjadi berdasarkan hubungan antara stimulus dengan respon yang relevan. Metode yang digunakan dalam penelitian ini adalah studi pustaka dimana penulis berusaha menemukan, menyusun dan menganalisis berbagai informasi melalui berbagai sumber terkait. Hasil penelitian ini menjelaskan bahwa belajar adalah suatu proses perubahan yang terjadi karena adanya syarat-syarat (conditions) yang kemudian menimbulkan reaksi (respons). Beberapa aspek yang tidak lepas dari teori ini yaitu lupa,
\end{abstract}


hukuman, dorongan, niat, dan transfer training. Edwin Ray Guthrie mencetuskan tiga metode yang bisa digunakan untuk mengubah tingkah laku kebiasaan, yaitu Metode Ambang (Threshold Ambang), Metode Kelelahan (Fatigue Method), dan Metode Reaksi Berlawanan (Incompatible Response Method). Ketiga metode tersebut dapat digunakan guru PAI dalam menerapkan pembelajarannya di kelas. Kontribusi positif dari artikel ini menginformasikan bahwa teori contiguous conditioning sangat cocok diaplikasikan untuk menumbuh kembangkan kemampuan peserta didik baik dari ranah kognitif, afektif, maupun psikomotorik. Salah satu cara agar teori ini bisa berjalan secara maksimal maka guru harus menggunakan metode atau strategi pembelajaran yang menarik.

\section{Kata Kunci: Contiguous, PAI, Edwin Ray Guthrie}

\section{A. Pendahuluan}

Pendidikan dan pembelajaran bagi setiap individu merupakan kebutuhan personal yang harus dipenuhi oleh setiap manusia guna meningkatkan taraf hidupnya dan mengangkat derajatnya, baik itu dilakukan ditingkat lingkungan keluarga sebagai organisasi terkecil, sekolah ataupun juga di lingkungan masyarakat. Pembelajaran dapat juga difahami sebagai upaya yang disengaja untuk mengelola kejadian atau peristiwa belajar. Dengan adanya proses pembelajaran tersebut maka manusia akan memperoleh sebuah pengetahuan baru dengan menggunakan metode tertentu.

Belajar merupakan suatu kegiatan yang cukup urgen dalam upaya pencapaian tujuan pendidikan. Tanpa belajar seseorang tidak mungkin bisa menjadi orang yang terdidik. Dengan kata lain orang yang terdidik adalah orang yang selalu gemar belajar. Dalam kehidupannya selalu berusaha untuk belajar dan berusaha untuk menjadi lebih baik lagi, dengan munculnya fenomena maupun masalah yang terjadi dalam kehidupan seorang peserta didik menjadikan mereka terpacu untuk belajar mandiri dalam mencapai tujuan yang diinginkan sehingga dalam dirinya tertanam suatu prinsip “tiada hari tanpa belajar”. Terlebih lagi dengan materi-materi keagamaan, mereka tentu akan berhati-hati dan selalu mengikuti apa yang ada dalam kerangka Pendidikan Agama Islam (PAI). Dalam melaksanakan kegiatan belajar pasti ada unsur orang yang mengajar (pengajar) 
dan orang yang di ajar (siswa), tanpa kedua unsur tersebut proses belajar mengajar tidak akan bisa terlaksana. Sebagaimana kita ketahui bersama bahwa seorang pengajar di sekolah yang disebut dengan guru diangkat untuk mengajar siswa tentu melalui proses yang ketat untuk menemukan seseorang yang profesional dan dianggap mampu untuk mengajarkan materi kepada siswa.

Namun pada kenyataannya masih terdapat guru-guru yang belum sepenuhnya memenuhi tugasnya sebagai pengajar dan pendidik sehingga mereka kurang memperhatikan dari segi kognitif, afektif maupun psikomotorik yang seharusnya dikuasai oleh siswa di bangku sekolah. Hal ini mungkin dapat dimengerti mengingat cukup banyak masalah yang terjadi pada seorang guru. Semua guru dihadapkan pada masalah-masalah, masalah banyaknya siswa dalam kelas, masalah ekonomi, dan masalah kenakalan anak-anak, masalah tekanan masyarakat yang kurang menghargai peranan guru dan sebagainya. ${ }^{1}$

Seorang guru harus mampu melaksanakan serangkaian kegiatan terencana dan terorganisasi dalam rangka menyampaikan materi pelajaran di dalam kelas. Terlebih lagi bagi seorang guru Pendidikan Agama Islam (PAI) yang mempunyai beban lebih berat karena harus mengajarkan materi-materi yang bersentuhan langsung dengan keyakinan (Iman, Islam, Ihsan). Guru Agama di sekolah umum dituntut lebih ekstra dalam menyampaikan materi dibandingkan dengan guru PAI yang mengajar di madrasah-madrasah. Praktek pembelajaran PAI di sekolah umum baik itu di sekolah dasar (SD), sekolah menengah pertama (SMP), sekolah menengah atas (SMA), dan sekolah menengah kejuruan (SMK) dipadatkan dalam satu mata pelajaran saja. Sedangkan praktek PAI pada madrasah mata pelajarannya dipisah-pisah menjadi empat bagian yakni Al-Qur’an Hadits, Akidah Akhlak, Fikih, dan Sejarah Kebudayaan Islam (SKI).

Dengan dipadatkannya materi PAI di sekolah umum menjadi satu mata pelajaran tentu menjadi tantangan bagi guru-guru dalam menyampaikan materi-materi tersebut kepada peserta didik. Salah satu efek yang ditimbulkan dengan adanya pemadatan tersebut yakni materi mata pelajaran PAI di sekolah

1 Sri Esti Wuryani Djiwandono, Psikologi Pendidikan, (Jakarta: PT. Grasindo, 2002), Hlm. 23. 
umum tidak bisa tuntas diberikan kepada siswa sebagaimana PAI yang ada di madrasah. Tantangan lain yang sering dijumpai pada sekolah-sekolah umum dalam menyampaikan materi PAI yaitu siswa merasa kesulitan menerima materi tersebut sehingga menyebabkan transfer ilmu yang diberikan oleh guru di kelas butuh waktu lumayan lama.

Secara umum permasalahan diatas terjadi karena dua faktor. Faktor pertama adalah faktor yang berasal dari guru, yaitu banyak guru yang suka mengambil jalan pintas dalam pembelajaran, baik dalam proses perencanaan, pelaksanaan, maupun proses evaluasi. Kondisi ini merupakan sebagai akibat dari asumsi para guru yang merasa dirinya sudah mengajar dengan baik. ${ }^{2}$ Sedangkan faktor yang kedua adalah faktor yang berasal dari orang tua atau wali murid, dimana sebetulnnya siswa lebih banyak mempunyai waktu di rumah dibandingkan dengan di sekolah. Tugas orang tua atau wali murid disini hendaknya bisa mengontrol dan memperhatikan perkembangan anak dalam mempelajari mata pelajaran yang telah diperoleh dari sekolah.

Teori kegiatan belajar sangat penting untuk dijadikan landasan dalam mengajar mata pelajaran kepada siswa. Adanya teori-teori yang beragam bisa membantu tenaga pengajar untuk menyampaikan materi dengan sempurna ketika di dalam kelas. Dengan menggunakan teori belajar yang tepat tentunya siswa juga akan cepat dalam menyerap materi pelajaran yang diberikan oleh guru.

Agar proses pembelajaran berjalan dengan baik, maka diperlukan keterampilan seorang guru dalam mengelola pembelajaran, baik itu berupa teori, strategi, model ataupun metode pembelajaran. Salah satu teori pembelajaran yang terkenal adalah teori pembelajaran Behavioristik. Teori ini mengkonsentrasikan pada kajian tentang perilaku-perilaku nyata yang bisa diteliti dan diukur. ${ }^{3}$ Teori ini memandang bahwa perilaku-perilaku khusus yang dirancang oleh guru akan membantu kegiatan belajar mengajar di dalam kelas sehingga bisa berjalan dengan efektif. Teori belajar behavioristik banyak yang sudah mempraktekkannya Hlm.20.

2 E. Mulyasa, Menjadi Guru Profesional, (Bandung: PT. Remaja Rosdakarya, 2008),

3 Mark K Smith, dkk, Teori Pembelajaran dan Pengajaran, (Yogyakarta: Mirza Media Pustaka, 2009), Hlm. 77. 
di dalam kegiatan pembelajaran, salah satu teori behavioristik yang akan dibahas dalam artikel ini yaitu teori contiguous conditioning yang dipelopori oleh Edwin Ray Guthrie dengan rujukan awal bersumber dari B.R. Hergenhahn \& Matthew H.Olson dalam bukunya yang berjudul Theories of Learning (Teori Belajar) yang diterjemahkan oleh Triwibowo B.S.

\section{B. Pembahasan}

\section{Metode Penelitian}

Metode studi yang dilakukan dalam penelitian ini adalah penelitian kepustakaan, artinya peneliti menggunakan literatur (kepustakaan). Setelah mengidentifikasi data yang diperoleh, penulis menyimpulkan tentang masalah yang dikaji, kemudian data yang sudah ada dianalisis. Adapun analisis yang digunakan adalah analisis deskriptif. Tujuan penelitian ini adalah untuk mengetahui gambaran teori belajar behavioristik Contiguity Edwin Ray Guthrie dan bagaimanakah desain rencana penerapan teori Contiguity dalam pembelajaran PAI di sekolah. Data yang dipergunakan adalah data sekunder yang diperoleh dari berbagai buku, jurnal, catatan, artikel, dan data yang dipublikasikan di internet.

Berdasarkan alur uraian diatas untuk menerapkan teori belajar behavioristik model contiguity Edwin Ray Guthrie dalam pembelajaran di sekolah, alur pembahasan ini ditata menjadi empat bagian. Bagian pertama melacak teori belajar model contiguous conditioning; kedua, mengidentifikasi cara kerja teori contiguous conditioning; dan keempat, menganalisis pengembangan teori contiguous conditioning dalam pembelajaran PAI di sekolah.

\section{Teori Belajar Aliran Behavioristik Contiguous Conditioning}

Teori adalah suatu pendapat yang didasarkan pada penelitian dan penemuan yang didukung oleh data dan argumentasi. ${ }^{4}$ Agus Suprijono menguraikan bahwa teori merupakan perangkat prinsip-prinsip yang terorganisasi mengenai peristiwa-peristiwa tertentu dalam lingkungan. Teori 
dikatakan sebagai hubungan kausalitas dari proposisi-proposisi. Ibarat bangunan, teori tersusun secara kausalitas atas fakta-fakta, variabel/konsep, dan proposisi. ${ }^{5}$ Teori sangatlah penting dibutuhkan dalam segala hal, tak terkecuali untuk bidang yang bergerak langsung dalam dunia pendidikan. Pendidikan tanpa mempraktekkan teori pembelajaran tentu akan menimbulkan masalah ketika menyampaikan materi langsung kepada siswa.

Sedangkan belajar adalah key term (istilah kunci) yang paling vital dalam setiap usaha pendidikan. Belajar adalah suatu aktifitas mental/psikis yangg berlangsung dalam interaksi aktif dengan lingkungan, yang menghasilkan perubahan-perubahan dalam pengetahuan, pemahaman, keterampilan, nilai sikap, dan perubahan itu bersifat secara relative konstan dan membekas. ${ }^{6}$ Belajar merupakan suatu proses yang ditempuh oleh manusia untuk memperoleh pengetahuan, yakni dari hal yang tidak tahu menjadi tahu. Belajar adalah suatu perubahan pada diri individu yang disebabkan oleh pengalaman dan terjadi dengan banyak cara, seperti contoh ketika siswa memperoleh informasi yang disampaikan oleh guru di kelas atau ketika sedang berperilaku sehari-hari.

Teori belajar behavioristik adalah sebuah teori yang dicetuskan oleh Gege dan Berliner tentang perubahan tingkah laku sebagai hasil dari pengalaman. Menurut teori behavioristik dalam belajar yang penting adalah input yang berupa stimulus dan output yang berupa respon. Stimulus adalah apa saja yang diberikan guru kepada siswa, sedangkan respon berupa reaksi atau tanggapan siswa terhadap stimulus yang diberikan oleh guru tersebut. ${ }^{7}$ Contoh stimulus dalam proses pembelajaran adalah daftar pertanyaan, alat peraga, pedoman kerja, dan cara-cara tertentu untuk membantu belajar siswa. Behavioristik memfokuskan diri pada sebuah pola perilaku baru yang diulangi sampai perilaku tersebut menjadi otomatis atau membudaya. Teori

4 El Rais, Kamus Ilmiah Populer, (Yogyakarta: Pustaka Pelajar, 2012), Hlm. 667.

5 Agus Suprijono, Cooperative Learning Teori dan Aplikasi Paikem, (Yogyakarta: Pustaka Pelajar, 2011), Hlm. 15.

6 W.S. Wingkel, Psikologi Pengajaran, (Jakarta: PT Gamedia, 1989), Hlm. 36.

7 Muhammad Siri Dangnga \& Andi Abd. Muis, Teori Belajar dan Pembelajaran Inovatif, (Makassar: Sibuku Makassar, 2015), Hlm. 68. 
belajar behavioristik berkonsentrasi pada kajian-kajian yang berkaitan dengan perilaku nyata serta bisa diteliti dan diukur.

Edwin Ray Guthrie dilahirkan pada tahun 1886 dan meninggal pada tahun 1959. Dia adalah seorang profesor psikologi di University of Washington mulai dari tahun 1914 sampai dengan pensiun tahun 1956. Karya dasarnya adalah The Psychology of Learning, yang dipublikasikan pada 1935 dan direvisi pada 1952. Gaya tulisannya mudah diikuti, penuh humor, dan menggunakan banyak kisah untuk menunjukkan contoh ide-idenya. ${ }^{8}$ Edwin merupakan salah satu tokoh yang mencetuskan teori pembelajaran dengan mengusung nilai-nilai behavioristik. Adapun teori yang diciptakan oleh Edwin Ray Guthrie dalam pembelajaran yaitu contiguous conditioning.

Teori contiguous conditioning adalah salah satu teori yang berlandaskan keyakinan behavioristik. Contiguous sendiri mempunyai arti kedekatan, sedangkan conditioning mempunyai arti kondisi. Sehingga bisa kita artikan bahwa contiguous conditioning yaitu sebuah kedekatan kondisi yang terjadi berdasarkan hubungan antara stimulus dengan respon yang relevan. Menurut paham teori contiguous conditioning, belajar itu adalah suatu proses perubahan yang terjadi karena adanya syarat-syarat (conditions) yang kemudian menimbulkan reaksi (respons). ${ }^{9}$ Dalam kegiatan pembelajaran akan banyak kita jumpai berbagai conditions yang berbeda-beda termasuk pula reaksi yang akan terjadi dengan adanya conditions tersebut. Dalam sekali pertemuan bisa kita temukan minimal sekitar lima sampai dengan tujuh conditions dalam satu kelas. Banyaknya conditions tersebut bisa dimanfaatkan oleh para guru dalam mengajarkan mata pelajaran di dalam kelas.

Guthrie beranggapan tentang kaidah yang dikemukakan oleh para teoritis seperti Thorndike dan Pavlov adalah ruwet dan tak perlu, dan sebagai penggantinya dia mengusulkan satu hukum belajar law of contiguity (hukum kontiguitas), yang dinyatakan bahwa kombinasi stimuli yang mengiringi

8 R. Hergenhahn \& Matthew H. Olson, Teori Belajar, Terj. Triwibowo B.S, (Jakarta: Kencana, 2017), Hlm. 225. 
suatu gerakan akan cenderung diikuti oleh gerakan itu jika kejadiannya berulang. ${ }^{10}$ Teori contiguous conditioning yang dipelopori oleh Edwin Ray Guthrie ini bisa dibilang cukup simple dan sederhana untuk diterapkan dalam dunia pendidikan.

\section{Cara Kerja Teori Contiguous Conditioning}

Eksperimen yang dilakukan oleh Guthrie untuk mendukung teori kontiguitas adalah percobaannya dengan kucing yang dimasukkan ke dalam kotak puzzle. Kemudian kucing tersebut berusaha keluar. Kotak dilengkapi dengan alat yang bila disentuh dapat membuka kotak puzzle tersebut. Selain itu, kotak juga dilengkapi alat yang dapat merekam gerakan-gerakan kucing di dalam kotak. Alat tersebut menunjukkan bahwa kucing telah belajar mengulang gerakan-gerakan sama yang diasosiasikan dengan gerakan-gerakan sebelumnya ketika dia dapat keluar dari kotak tersebut. ${ }^{11}$ Dari percobaan tersebut dapat kita ketahui bahwa kucing-kucing yang dijadikan sampel untuk penelitian ini mempunyai cara yang berbeda-beda untuk bisa keluar dari kotak puzzle yang telah disiapkan oleh Guthrie. Jika kucing sudah mengetahui bagaimana formula yang tepat untuk bebas dari perangkap kotak tersebut, maka kucing-kucing itu akan berusaha semaksimal mungkin melalui gerakan-gerakan yang sama dan dilakukan berulang-ulang sampai berhasil membuka kunci kotak puzzle tersebut dan keluar dengan sendirinya.

Teori contiguous conditioning secara umum tidak jauh berbeda dengan teori lain yang dicetuskan oleh para tokoh behavioristik lainnya. Dalam teori ini memang peran dari seorang yang memberi stimulus harus benar-benar disiapkan dan disampaikan secara spesifik dengan tujuan agar individu yang mendapat stimuli tersebut bisa merespon dengan cepat dan tepat. Banyak respon yang tentunya bisa memunculkan gerakan-gerakan tertentu untuk mengatasi stimulus yang diberikan. Antara respon satu dengan

9 Sarwo Edy \& Sri Uchtiawati, Teori Belajar. (Gresik: UMG Press, 2017), Hlm. 47.

10 Sarwo Edy \& Sri Uchtiawati, Teori Belajar..., Hlm. 48.

11 Baharuddin \& Esa Nur Wahyuni, Teori Belajar \& Pembelajaran, (Yogyakarta: Ar-Ruzz Media, 2007), Hlm. 82. 
respon lainnya bisa jadi berbeda mengingat individu yang menerima stimulus tersebut terdiri dari beranera ragam pula. Seseorang yang memberikan stimulus juga harus faham terhadap kondisi perbedaan tersebut sehingga tidak menimbulkan kesulitan dalam menerima respon.

Cara kerja teori contiguous conditioning ini juga tak lepas dari aspek-aspek seperti lupa, hukuman, dorongan, niat, dan transfer training. Untuk itu agar para calon pelaku teori ini bisa lebih memahaminya dengan baik, Guthrie memberikan penjelasannya sebagai berikut: ${ }^{12}$

Pertama, Lupa disebabkan oleh munculnya respons alternatif dalam satu pola stimulus. Setelah pola stimulus menghasilkan respons alternatif, pola stimulus itu kemudian akan cenderung menghasilkan respons baru. Kedua, Hukuman Efektivitas punishment ditentukan oleh apa penyebab tindakan yang dilakukan oleh organisme yang dihukum itu. Hukuman bekerja baik bukan karena rasa sakit yang dialami oleh individu terhukum, tetapi karena hukuman mengubah cara individu meresmpons stimuli tertentu. Ketiga, Dorongan fisiologis merupakan apa yang oleh Guthrie disebut Maintaining stimuli (stimuli yang mempertahankan) yang menjaga organisme tetap aktif sampai tujuan tercapai. Keempat, Respon yang dikondisikan ke maintaining stimuli dinamakan intensions (niat). Respons itu dinamakan niat karena maintaining stimuli dari dorongan biasanya berlangsung selama periode waktu tertentu (sampai dorongan berkurang). Dan Kelima adalah Transfer Training, Guthrie dalam hal ini kurang terlalu berharap karena pada dasarnya seseorang menunjukkan respons yang sesuai dengan stimuli jika pada kondisi yang sama.

Dalam menerapkan teori contiguous conditioning akan menjumpai kebiasaan-kebiasaan yang terjadi di lapangan. Ada kebiasaan yang sesuai namun ada juga kebiasaan-kebiasaan yang tidak sesuai. Apabila kebiasaan tersebut sudah sesuai maka bisa lanjutkan, namun ketika menemui kebiasaan yang inapropiate (tidak sesuai), maka kebiasaan itu perlu diputus. Untuk itu perlu memutus pula hubungan antara asosiasi dengan 'cues' (yang 
memunculkan stimuli dan respons) ${ }^{13}$. Setidaknya ada tiga metode yang ditawarkan oleh Guthrie untuk mengubah tingkah laku kebiasaan, yaitu: ${ }^{14}$

a. Metode Ambang (Threshold Ambang)

Metode mencari petunjuk yang memicu kebiasaan buruk dan melakukan respon lain saat petunjuk itu muncul. Misalnya ada seorang siswa yang suka ramai di belakang kelas, untuk menghentikan kebiasaan ramai siswa tersebut, guru dapat memindahkan tempat duduknya ke baris depan.

b. Metode Kelelahan (Fatigue Method)

Hubungan antara stimulus dan reaksi yang buruk itu dibiarkan saja sampai pelakunya merasa bosan. Sebagai contoh ada seorang siswa yang suka membuat catatan kecil untuk mencontek, maka untuk menghentikan perilaku buruk itu seorang guru bisa menyuruh siswa tersebut membuat catatan berlembar-lembar secara terus menerus sehingga ia akan bosan dengan sendirinya.

c. Metode Reaksi Berlawanan (Incompatible Response Method)

Metode ini menganggap manusia adalah suatu organisme yang selalu mereaksi kepada stimulus-stimulus tertentu. Jika suatu reaksi terhadap stimulus tertentu telah menjadi kebiasaan, maka cara untuk mengubahnya adalah dengan cara menghubungkan stimulus dengan reaksi yang berlawanan dengan reaksi yang hendak dihilangkan. Misalnya seorang murid yang merasa ketakutan saat disuruh gurunya maju untuk mengerjakan soal di papan tulis, untuk menghilangkan perasaan takut murid tersebut guru bisa menyuruh siswa maju terus menerus tiap ada soal yang hendak dikerjakan di papan tulis.

Edwin Guthrie menggunakan variabel hubungan stimulus dan respon untuk menjelaskan terjadinya proses belajar. Namun ia mengemukakan bahwa stimulus tidak harus berhubungan dengan kebutuhan atau pemuasan biologis sebagaimana yang dijelaskan oleh Clark dan Hull. Guthrie

13 Baharuddin \& Esa Nur Wahyuni, Teori Belajar..., Hlm. 80. 
menjelaskan bahwa hubungan antara stimulus dan respon cenderung hanya bersifat sementara, oleh sebab itu dalam kegiatan belajar siswa perlu sesering mungkin diberikan stimulus agar hubungan antara stimulus dan respon bersifat lebih tetap. ${ }^{15}$ Kapasitas otak dari tiap siswa pasti berbeda-beda, mereka ada yang mempunyai kapasitas yang sangat tinggi namun sebaliknya juga ada mereka-mereka yang memiliki kapasitas yang sedang atau bahkan rendah. Bagi yang mempunyai kapasitas daya ingat tinggi mungkin mereka akan mudah dalam belajar di dalam kelas, tapi bagi siswa yang merasa susah dalam belajarnya seorang guru wajib memberikan stimulus sesering mungkin agar mereka selalu ingat terhadap apa yang telah diajarkan. Ada beberapa prinsip belajar yang diajukan oleh Guthrie, yaitu: ${ }^{16}$

a) Bahwa yang terpenting adalah prinsip persyaratan (conditioning).

b) Prinsip pengendalian persyaratan yakni respon akan dikendalikan jika respon lain timbul dengan adanya S-R asli.

c) Adanya persyaratan yang ditunda.

d) The law of association.

e) Pengembangan (perbaikan) performance atau tindakan merupakan hasil praktek.

Menurut Guthrie peningkatan hasil belajar itu bukanlah hasil berbagai respon yang kompleks terhadap stimulus-stimulus yang ada, melainkan karena dekatnya asosiasi antara stimulus dengan respon yang diperlukan. ${ }^{17}$ Ciri khas dari teori ini adalah contiguity atau kedekatan, sehingga bisa kita prediksi ketika asosiasi tersebut berjarak jauh antara stimulus dengan respon tentu peningkatan hasil belajar bisa tercipta lumayan lama. Kedekatan hubungan antara stimulus dan respon sangat diperlukan oleh seorang guru ketika mengajar di dalam kelas agar tujuan pembelajaran bisa tercapai dengan sempurna.

14 Sarwo Edy \& Sri Uchtiawati, Teori Belajar..., Hlm. 52-53.

15 Pendidikan Profesi Guru, Modul Teori Belajar dan Pembelajaran, (Purwokerto: IAIN Purwokerto, 2015), Hlm. 5.

16 Makmun Khairani, Psikologi Belajar, (Yogyakarta: Aswaja Presindo, 2013), Hlm. 20.

17 Evi Aeni Rufaedah, Teori Belajar Behavioristik Menurut Perspktif Islam, Risalah, Jurnal Pendidikan dan Studi Islam. Volume 4, Nomor 1, Desember 2017, Hlm. 20. 


\section{Pengembangan Teori Contiguous Conditioning Dalam Pendidikan Agama Islam di Sekolah}

Kemampuan untuk belajar merupakan sebuah karunia Allah yang mampu membedakan manusia dengan makhluk yang lain. Allah menganugerahkan akal kepada manusia untuk mampu belajar dan menjadi pemimpin di dunia ini. Pendapat yang mengatakan bahwa belajar sebagai aktivitas dari kehidupan manusia ternyata bukan berasal dari hasil renungan manusia semata, ajaran agama sebagai pedoman hidup manusia juga menganjurkan manusia untuk selalu melakukan kegiatan belajar. ${ }^{18}$ Semua agamanya mengajarkan kepada umatnya untuk belajar dalam bidang apapun, tak terkecuali bagi agama Islam utamanya di negara Indonesia yang mayoritas penduduknya berstatus sebagai Muslim.

Berdasarkan teori contiguous conditioning dari Guthrie, setiap individu mempunyai kepasitas belajar yang berbeda. Dari hasil penelitiannya terhadap sejumlah binatang, Guthrie mengatakan bahwa tidak semua binatang mempunyai tingkat sensitivitas yang sama dengan satu stimulus, dan semua binatang memiliki indera yang sama untuk menerima informasi. Disamping itu, menurut Guthrie latihan akan mengakomodasikan ataupun menghilangkan respons tertentu sehingga atas kombinasi stimulus yang muncul dapat dihasilkan suatu respons yang menyeluruh sebagaimana yang diharapkan dapat disebut sebagai suatu kinerja yang berhasil. ${ }^{19}$

Begitupun juga jika teori contiguous conditioning ini diterapkan pada manusia tentu akan mengakibatkan hasil yang berbeda pula. Siswa satu dengan yang lainnya mempunyai kelengkapan indera yang sama, namun belum tentu dengan indera yang sama tersebut siswa akan sama pula kemampuannya dalam menanggapi stimulus yang diberikan oleh guru. Mata pelajaran PAI di sekolah umum bisa memberikan banyak warna dengan

18 Muhammad Siri Dangnga \& Andi Abd. Muis, Teori Belajar dan Pembelajaran Inovatif, (Makassar: Sibuku Makassar, 2015), Hlm. 1.

19 Tutik Rachmawati \& Daryanto, Teori Belajar dan Proses Pembelajaran Yang Mendidik, (Yogyakarta: Penerbit Gava Media, 2015), Hlm. 57. 
menghadirkan teori contiguous conditioning ini kepada siswa yang beraneka ragam latar belakangnya. Dengan beragamnya latar belakang tersebut membuat guru untuk selalu tampil kreatif dan inovatif dalam menyampaikan materi ketika di dalam kelas.

Seorang guru PAI bisa menyiapkan berbagai stimulus untuk diberikan kepada siswanya agar siswa tersebut bisa lebih mudah menerima materi pelajaran yang disampaikan guru di dalam kelas. Semakin banyak stimulus yang disiapkan oleh guru, maka semakin banyak pula respon yang akan diterima guru tersebut di dalam kelas. Selanjutnya dari respon-respon tersebut bisa dijadikan guru sebagai landasan dalam menyiapkan stimulus selanjutnya yang akan diterapkan kepada siswa yang berbeda dan angkatan yang berbeda. Secara tidak langsung seorang guru mempunyai tabungan stimulus-stimulus yang bisa diterapkan untuk masa yang akan datang. Bisa jadi masa saat ini dengan masa yang akan datang akan terjadi banyak perubahan, hal tersebut bisa menyebabkan terjadinya perubahan situasi belajar dalam kegiatan pembelajaran. Situasi belajar untuk masa depan mungkin tidak bisa kita prediksi, namun setidaknya sebagai seorang guru bisa mengantisipasinya dengan pengalaman-pengalaman yang sudah ada.

Setiap situasi belajar merupakan gabungan berbagai stimulus dan respon, dalam situasi tertentu banyak stimulus yang berasosiasi dengan banyak respon. ${ }^{20}$ Hal ini tentu tidak bisa dipungkiri bahwa sesungguhnya ketika menerapkan teori contiguous conditioning dalam kegiatan belajar PAI akan mendapatkan respon-respon baru yang bisa berpengaruh pula kepada lahirnya stimulus baru. Kemudian stimulus dan respon tersebut akan berjalan secara continue sampai dengan situasi yang tidak bisa ditentukan.

Implikasi dari teori contiguous conditioning dalam proses pembelajaran PAI bisa diterapkan pada semua jenjang sekolah, mulai dari SD, SMP dan SMA/SMK. Teori ini juga bisa diterapkan pada semua materi ajar PAI, namun beberapa materi mungkin akan terasa kurang efektif untuk

20 Yuberti, Teori Pembelajaran dan Pengembangan Bahan Ajar Dalam Pendidikan, (Lampung: Anugrah Utama Raharja, 2014), Hlm. 30. 
diterapkan karena mempunyai tingkat kesulitan serta kemudahan yang berbeda-beda. Secara psikologis memang antara anak SD dan SMP berbeda, kemudian siswa SMP berbeda pula dengan siswa yang duduk di bangku SMA maupun SMK. Namun dalam pengondisian teori ini seorang guru bisa memberikan stimulus kepada siswa sesuai dengan kapasitas kemampuan yang dimilikinya.

Pendidikan Agama dimaksudkan untuk meningkatkan potensi spiritual dan membentuk peserta didik agar menjadi manusia yang beriman dan bertakwa kepada Tuhan Yang Maha Esa dan berakhlak mulia. Akhlak mulia mencakup etika, budi pekerti,dan moral. Peningkatan potensi spiritual mencakup pengenalan, pemahaman, dan penanaman nilai-nilai keagamaan, serta pengamalan nilai-nilai tersebut dalam kehidupan individual maupun kolektif kemasyarakatan. Peningkatan potensi spiritual tersebut pada akhirnya bertujuan pada optimalisasi berbagai potensi yang dimiliki manusia yang aktualisasinya mencerminkan harkat dan martabatnya sebagai makhluk Tuhan.

Aplikasi teori contiguous conditioning dalam kegiatan pembelajaran PAI di sekolah tergantung dari beberapa hal seperti: tujuan pembelajaran, bahan atau materi pelajaran, karakteristik siswa, media dan fasilitas pembelajaran yang tersedia di sekolah. Selain itu penilaian atau evaluasi juga diperlukan untuk mengukur sejauh mana teori ini berfungsi. Dengan kata lain untuk penerapan teori contiguous conditioning dalam pembelajaran bisa dituangkan dalam Rencana Pelaksanaan Pembelajaran (RPP). Setiap guru yang mengajar di kelas pasti memiliki RPP atau bisa juga disebut rundown kegiatan belajar di kelas untuk semua materi dari awal semester hingga akhir semester.

Untuk menentukan posisi stimulus dan respon dalam kegiatan belajar seorang guru bisa meletakkan ruh teori ini pada tahap langkah-langkah kegiatan pembelajaran di bagian inti (tengah). Dibagian tersebut guru bisa memberikan stimulus yang spesifik terhadap materi yang diajarkan kepada peserta didiknya. Semisal untuk siswa yang duduk di bangku SD seorang 
guru bisa memberikan stimulus dengan cara memberikan pertanyaan secara lisan kepada siswa. Di usia anak-anak mereka akan saling berebut mengangkat tangannya atau telunjuk jarinya untuk memberikan respon kepada guru Agama yang memberikan pertanyaan tersebut.

Konsep teori contiguous conditioning dalam pembelajaran PAI di sekolah mengusung adanya perilaku atau gerakan-gerakan yang timbul atas stimulus yang diberikan oleh guru. Semisal dalam pembelajaran PAI ditingkat SMP dapat kita contohkan pada materi praktik Shalat yang dilaksanakan di Masjid atau Musholla sekolah. Seorang guru Agama dengan memberikan perintah (stimulus) kepada siswa yang dipanggil untuk maju ke depan dan mempraktikkan gerakan shalat baik itu takbiratul ihram, rukuk, i’tidal sujud, dan gerakan lainnya. Maka siswa yang ditunjuk tersebut akan maju dan segera mempraktikkan apa yang diperintahkan oleh sang guru tercinta. Contoh lainnya adalah ketika siswa mendengarkan kumandang Adzan baik itu sekolah maupun di rumah maka siswa tersebut akan bergegas untuk segera pergi ke Masjid, karena suara Adzan tersebut merupakan suatu stimulus (perintah) untuk segera menunaikan ibadah Shalat yang merupakan sebuah kewajiban bagi orang Muslim.

Cara kerja teori contiguous conditioning dalam pembelajaran PAI di sekolah merupakan kedekatan hubungan antara stimulus dan respon yang relevan. Stimulus yang diberikan guru sebagai alat memancing siswa agar bisa merespon dengan cepat dan tepat. Ketika guru ingin memancing didalam kolam ikan tentu harapannya akan memperoleh hasil tangkapan ikan. Nah, ketika didalam kolam tersebut terdapat berbagai binatang air hendaknya binatang tersebut tidak mengambil jatah umpan yang memang diberikan untuk ikan yang dipancing. Sehingga dengan begitu antara stimulus (umpan ikan) akan relevan jika yang memakannya adalah ikan pula. Biasanya dalam teori contiguous conditioning ini agak susah dipraktekkan pada siswa di jenjang SMA/SMK dengan asumsi bahwa mereka sudah remaja dan beranjak menuju dewasa, sehingga pola pikirnya juga akan mengikuti sesuai dengan 
tingkat usianya. Namun dengan kasus tersebut dapat mengindikasikan bahwa teori contiguous conditioning sedang bekerja dalam proses pembelajaran.

Isi dari teori contiguous conditioning dalam Pembelajaran PAI di sekolah yaitu terletak pada metode atau strategi pembelajaran yang dilaksanakan didalam kelas. Untuk mendesain stimulus yang tepat bagi siswa diperlukan sebuah ketrampilan guru dalam menyusun strategi pembelajaran. Pengembangan metode dan strategi pembelajaran sangat penting dibutuhkan karena aspek tersebut bisa dibilang jantung dari proses pembelajaran yang tertuang dalam dokumen pembelajaran yang biasa kenal dengan sebutan RPP. Materi satu dengan materi berikutnya belum tentu sama penerapan strategi pembelajarannya, hal ini bisa terjadi karena terdapat perbedaan pada materi pelajaran dan bisa dilihat dari faktor kemudahan atau kesulitan materi itu sendiri.

Contoh RPP penerapan dari teori contiguous conditioning dalam pembelajaran PAI di SMK yakni bisa dengan menerapkan model pembelajaran discovery learning yaitu metode mengajar yang mengatur pengajaran sedemikian rupa sehingga siswa memperoleh pengetahuan yang sebelumnya belumm diketahuinya itu tidak melalui pemberitahuan, sebagian atau seluruhnya ditemukan sendiri. Dalam desain RPP pada kegiatan inti tersebut bisa kita amati beberapa stimulus yang diberikan oleh guru kepada para siswa. Dalam kemasan RPP tersebut guru sudah berusaha untuk membuat siswa bisa menerima respon semuanya dengan cara memberikan tugas-tugas yang harus dikerjakan oleh siswa. Pada rancangan RPP tersebut siswa diarahkan untuk bisa aktif selama kegiatan pembelajaran berlangsung. Selain itu siswa juga akan mulai terbiasa untuk berfikir linear dan konvergen setiap kali mengikuti proses pembelajaran.

Teori contiguous conditioning Guthrie juga mendukung program magang atau mentoring dan mendorong pendekatan pertukaran pelajar untuk memperluas pengalaman belajar. ${ }^{21}$ Di sekolah yang berbasis vokasional seperti SMK terdapat salah satu kewajiban untuk menjalankan program 
Prakerin (Praktik Kerja Industri) sebelum mereka lulus, hal ini dimaksudkan agar para siswa tersebut mempunyai bekal sesuai dengan jurusan yang dipilihnya untuk menjadi manusia yang unggul dan berprestasi. Program prakerin atau yang biasa kita kenal dengan PPL (Praktek Kerja Lapangan) maupun magang menurut Guthrie ini bisa memperkaya pengalaman siswa.

Beberapa kelemahan teori contiguous conditioning dalam pembelajaran PAI yang telah dikembangkan pada sekolah umum diantaranya pada proses pembelajaran yang terjadi di dalam kelas lebih berfokus dari guru, stimulus dari guru menjadi peran penting dalam menerapkan teori ini. Kemudian efek dari teori ini jika dilaksanakan dalam pembelajaran PAI sebagaimana pada contoh RPP diatas, akan terjadi kecemburuan sosial diantara sesama siswa dalam satu kelas. Bagi siswa yang bisa menjawab pertanyaan dari guru maka ia bisa mendominasi dalam pembelajaran ini. Sedangkan bagi siswa yang tidak mampu maka ia akan lebih memilih untuk diam saja sambil menunggu stimulus yang diberikan oleh guru.

Sedangkan untuk keunggulan dari teori contiguous conditioning dalam pembelajaran PAI yang telah dikembangkan pada sekolah yaitu siswa mempunyai sifat berani dalam kegiatan belajar mengajar, mereka bisa mencurahkan segala pemikiran dan ide-ide kreatifnya untuk merespon stimulus yang diberikan oleh guru PAI. Mereka bisa lebih fokus untuk menerima stimulus-stimulus yang diberikan oleh guru PAI, siswa menjadi aktif dan produktif dalam pembelajaran tersebut. Kemudian siswa juga bisa lebih semangat dalam mengikuti proses pembelajaran ketika sesekali siswa tersebut mendapatkan hadiah dari guru.

Pendidikan Agama Islam diharapkan menghasilkan manusia yang selalu berupaya menyempurnakan iman, takwa, dan akhlak, serta aktif membangun peradaban dan keharmonisan kehidupan, khususnya dalam memajukan peradaban bangsa yang bermartabat. Manusia seperti itu diharapkan tangguh dalam menghadapi tantangan, hambatan, dan perubahan

21 B. R. Hergenhahn \& Matthew H. Olson, Teori Belajar..., Hlm. 246. 
yang muncul dalam pergaulan masyarakat baik dalam lingkup lokal, nasional, regional maupun global.

\section{Kesimpulan}

Teori contiguous conditioning adalah salah satu teori yang berlandaskan keyakinan behavioristik. Contiguous conditioning mempunyai makna sebuah kedekatan kondisi yang terjadi berdasarkan hubungan antara stimulus dengan respon yang relevan. Menurut paham teori contiguous conditioning, belajar itu adalah suatu proses perubahan yang terjadi karena adanya syarat-syarat (conditions) yang kemudian menimbulkan reaksi (respons).

Dalam proses pembelajaran PAI di sekolah umum, teori ini lumayan efektif untuk dijalankan oleh para guru-guru. Letak kunci teori ini bisa dituangkan guru dalam Rencana Pelaksanaan Pembelajaran (RPP). Semakin banyak stimulus yang diberikan guru kepada siswa maka semakin banyak pula respon yang akan diterima. Penyusunan RPP tersebut sangat vital untuk disiapkan oleh semua guru, tanpa adanya RPP yang matang proses pembelajaran akan tersasa hambar dan tujuan pembelajaran bisa jadi tidak akan tercapai. Disinilah fungsi guru agar menjalankan tugasnya dalam menjalankan amanah yang diberikan wali siswa dengan sebaik mungkin. Sehingga ketika para guru terbiasa menjalankan teori belajar yang telah disusun, derajat keterampilan mengajarnya akan ikut menanjak. Mereka akan mempunyai nyawa yang lebih ketika mengajar di dalam kelas dan akhirnnya mereka dinilai menjadi manusia yang mempunyai nilai-nilai bijaksana yang tinggi.

Selanjutnya keberhasilan siswa dalam belajar di sekolah tergantung bagaimana guru mengarahkan siswa tersebut ketika proses pembelajaran berlangsung, sukses gagalnya siswa memahami materi di kelas menjadi tolok ukur seorang guru dalam mentransfer ilmu. Salah satu upaya yang harus diterapkan guru ketika mengajar yakni dengan menggunakan metode atau strategi belajar yang menarik bagi siswa. Karena dengan cara tersebut guru bisa mengambil hatinya siswa untuk menjadi tertarik terhadap materi yang diajarkan, dan sehingga membuat materi tersebut berhasil disenangi dan difahami oleh siswa. 


\section{DAFTAR PUSTAKA}

Aeni Rufaedah, Evi. 2017. Teori Belajar Behavioristik Menurut Perspktif Islam, Risalah, Jurnal Pendidikan dan Studi Islam. Volume 4, Nomor 1.

Baharuddin \& Esa Nur Wahyuni. 2007. Teori Belajar \& Pembelajaran. Yogyakarta: Ar-Ruzz Media.

Edy, Sarwo \& Sri Uchtiawati. 2017. Teori Belajar. Gresik: UMG Press.

Mulyasa. 2008. Menjadi Guru Profesional. Bandung: PT. Remaja Rosdakarya.

El Rais. 2012. Kamus Ilmiah Populer. Yogyakarta: Pustaka Pelajar.

Esti Wuryani Djiwandono, Sri. 2002. Psikologi Pendidikan. Jakarta: PT. Grasindo.

FuadAh. Zakki, Jauharoti Alfin, and NasihAhmad Munjin. 2017. "Membangun Etika Dan Kepribadian Di Lembaga Pendidikan Islam: Sebuah Perspektif Psikologi Qur’ani”. Jurnal Pendidikan Agama Islam (Journal of Islamic $\begin{array}{lllll}\text { Education } & \text { Studies) } & 5 & \text { (2), }\end{array}$ https://doi.org/10.15642/jpai.2017.5.2.309-338.

Harjanto. 2008. Perencanaan Pengajaran. Jakarta: Rineka Cipta.

Khairani, Makmun. 2013. Psikologi Belajar. Yogyakarta: Aswaja Presindo.

March, David S., Micheal A. Olson, and Russell H. Fazio. 2019. “The Implicit Misattribution Model of Evaluative Conditioning”. Social Psychological Bulletin 13 (3), 1-25. https://doi.org/10.5964/spb.v13i3.27574.

Mark K Smith, dkk. 2009. Teori Pembelajaran dan Pengajaran. Yogyakarta: Mirza Media Pustaka.

Pendidikan Profesi Guru. 2015. Modul Teori Belajar dan Pembelajaran. Purwokerto: IAIN Purwokerto.

Rachmawati, Tutik \& Daryanto. 2015. Teori Belajar dan Proses Pembelajaran Yang Mendidik. Yogyakarta: Penerbit Gava Media.

R. Hergenhahn \& Matthew H. Olson. 2017. Teori Belajar, Terj. Triwibowo B.S. Jakarta: Kencana.

Siri Dangnga, Muhammad \& Andi Abd. Muis. 2015. Teori Belajar dan

Pembelajaran Inovatif. Makassar: Sibuku. 
Suprijono, Agus. 2011. Cooperative Learning Teori dan Aplikasi Paikem. Yogyakarta: Pustaka Pelajar.

W.S. Wingkel. 1989. Psikologi Pengajaran. Jakarta: PT Gamedia.

Yuberti. 2014. Teori Pembelajaran dan Pengembangan Bahan Ajar Dalam Pendidikan. Lampung: Anugrah Utama Raharja. 